\title{
Cleft Lip/Palate, Short Stature, and Developmental Delay in a Boy with a 5.6-Mb Interstitial Deletion Involving 10p15.3p14
}

\author{
Bruno F. Gamba ${ }^{a}$ Carla Rosenberg $^{b}$ Silvia Costa ${ }^{b}$ Antonio Richieri-Costa ${ }^{c}$ \\ Lucilene A. Ribeiro-Bicudo ${ }^{a}$ d \\ Departments of a Genetics and ${ }^{\mathrm{b}} \mathrm{Genetics}$ and Evolutionary Biology, Institute of Biosciences and ${ }^{\mathrm{c} S y n d r o m o l o g y}$ \\ Division, Hospital for Rehabilitation of Craniofacial Anomalies (HRAC), University of São Paolo, São Paulo, and \\ ${ }^{\mathrm{d}}$ Department of Genetics, Institute of Biosciences, Federal University of Goias, Goiânia, Brazil
}

\section{Key Words}

10p15 deletion · Array-CGH · Cleft lip/palate · DiGeorge syndrome 2

\begin{abstract}
The chromosome interval 10p15.3p14 harbors about a dozen genes. This region has been implicated in a few wellknown human phenotypes, namely HDR syndrome (hypoparathyroidism, sensorineural deafness, and renal dysplasia) and DGS2 (DiGeorge syndrome 2), but a number of variable phenotypes have also been reported. Cleft lip/palate seems to be a very unusual finding within the clinical spectrum of patients with this deletion. Here, we report a male child born with short stature, cleft lip/palate, and feeding problems who was found to have a 5.6-Mb deletion at 10p15.3p14.
\end{abstract}

(c) 2015 S. Karger AG, Basel

Patients with 10p15.3p14 deletions can present with clinical findings including hypoparathyroidism, heart defects, immunodeficiency, deafness, renal malformations, neurocognitive alterations, motor delay, hypoto-

\section{KARGER 125}

(c) 2015 S. Karger AG, Basel

1661-8769/15/0061-0039\$39.50/0

E-Mail karger@karger.com

www.karger.com/msy nia, seizures, and craniofacial dysmorphism among other less frequent findings [Verri et al., 2004; Lindstrand et al., 2010; DeScipio et al., 2012]. Usually, more distally located deletions are associated with HDR syndrome (hypoparathyroidism, sensorineural deafness, and renal dysplasia), while more proximally located deletions are associated with DiGeorge syndrome 2 (DGS2) [Lichtner et al., 2000; Van Esch et al., 2000; Melis et al., 2012]. However, none of these phenotypes is associated with cleft lip/ palate in the clinical spectrum. Among facial findings, cleft lip/palate has seldom been reported. Here, we describe a male patient presenting with bilateral cleft lip/ palate, delayed psychomotor development, and feeding problems who was found to have a deletion involving 10p15.3p14 without the classical findings of either DGS2 or HDR.

\section{Materials and Methods}

Case Report

A male patient (fig. 1) was referred to the Hospital for Rehabilitation of Craniofacial Anomalies, USP at the age of 3 months for assessment and management of cleft lip/palate. He was the 

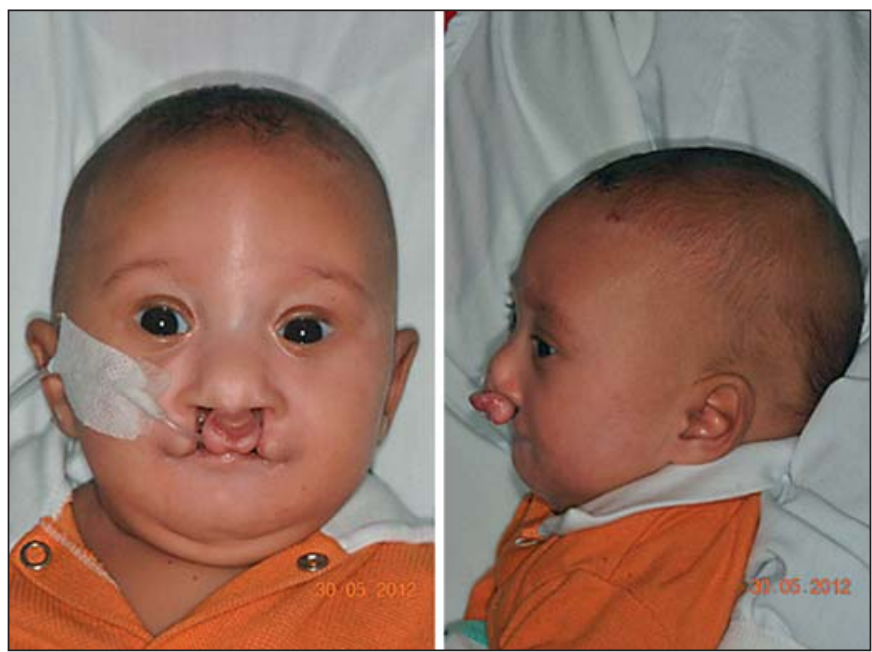

Fig. 1. Facial appearance of the patient. first child of a healthy and unrelated couple. The pregnancy was unremarkable with no exposure to known teratogens, and there was no relevant family history. Delivery was at 34 weeks of gestation by cesarean section; birth weight was $1,400 \mathrm{~g}$ ( $<3 \mathrm{rd}$ centile), length was $39 \mathrm{~cm}$ ( $<3$ rd centile), and OFC was $27 \mathrm{~cm}(<3 \mathrm{rd}$ centile). He cried immediately at birth, Apgar scores at 1 and 5 min were 8 and 9, respectively, and a bilateral cleft lip/palate was noticed. Neonatal heel prick sample test results were unremarkable. He remained at the hospital due to feeding problems during the first month of life. Since the age of 3 months, he has been fed through a nasogastric feeding tube but with no satisfactory weight gain. At the age of 8 months, his weight was $4,250 \mathrm{~g}(<3 \mathrm{rd}$ centile), his length was $58.5 \mathrm{~cm}(<3 \mathrm{rd}$ centile), and his OFC was $38.5 \mathrm{~cm}$ ( $<3$ rd centile). Neuropsychological development was delayed; he had normal cervical control and was able to roll over, but he could not sit without support. Further examinations showed mild prominence of the metopic suture, telecanthus, upslanted palpebral fissures, epicanthus inversus, a broad and low nasal root, and bilateral cleft lip/palate. Upper and lower limbs, the spine, and the cardiovascular system were normal, and results of blood laboratory tests were also in the normal range. A BERA test was recently performed and turned out unremarkable. Also, kidney ultrasound was performed at the age of 12 months and did not show any anomalies.

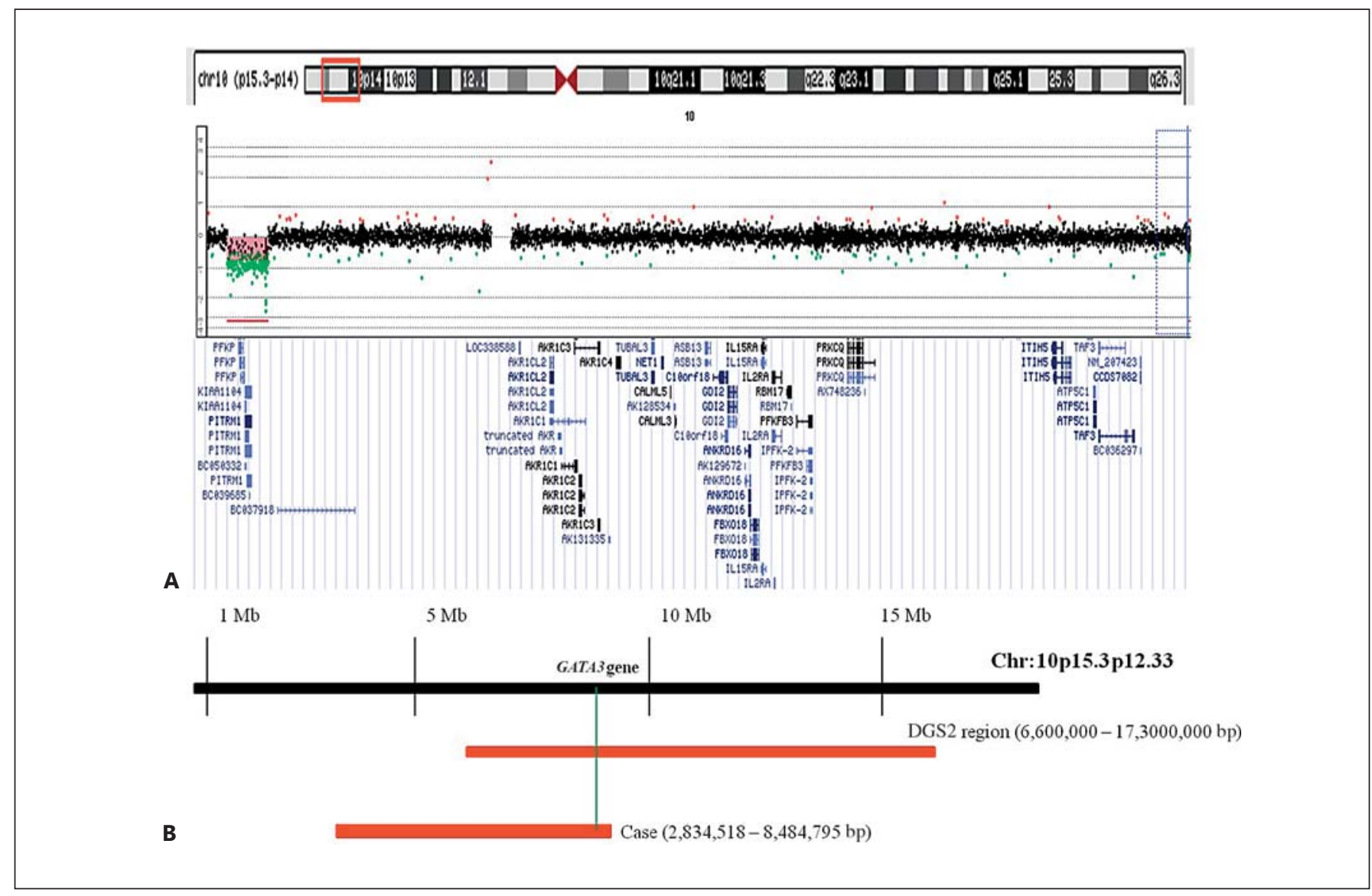

Fig. 2. A Array-CGH profile of the 5.6-Mb interstitial deletion at the short arm of chromosome 10. B DGS2-deleted region and the 10 p15.3p14 deletion in the present case (red bars). The green line indicates the deletion of the GATA3 gene in both deleted regions.

40
Mol Syndromol 2015;6:39-43 DOI: $10.1159 / 000371404$
Gamba/Rosenberg/Costa/Richieri-Costa/ Ribeiro-Bicudo 


\section{Cytogenetics}

Chromosomal analyses were performed on peripheral blood samples using conventional GTG-banding techniques at the 550band level.

\section{Array Comparative Genomic Hybridization}

Array comparative genomic hybridization (array-CGH) using the whole genome Cytosure ${ }^{\mathrm{TM}}$, ISCA V2 array $4 \times 180 \mathrm{~K}$ (Oxford Gene Technology, UK) was performed according to the manufacturer's instructions. Scanned images of the arrays were processed and analyzed using Feature Extraction software and Genomic Workbench software (Agilent Technologies) with the statistical algorithm ADM-2 and a sensitivity threshold of 6.0. We applied a 'loop design' in our hybridizations as previously described [Allemeersch et al., 2009], resulting in 2 reverse labeling hybridizations per sample. To be recognized by the software, alterations had to encompass at least 3 consecutive probes with aberrant $\log _{2}$ values, and those not detected in both dye-swap experiments of the same sample were excluded from the analysis.

Table 1. Genes contained in the 10p15.3p14 deletion

\begin{tabular}{|c|c|}
\hline Gene & Function \\
\hline PFKP & Phosphofructokinase, key regulatory enzyme in glycolysis \\
\hline KLF6 & Kruppel-like factor 6, transcription factor, tumor suppressor \\
\hline$A K R 1 C 2$ & $\begin{array}{l}\text { Encodes a member of the aldo/keto reductase superfamily which consists of more than } 40 \text { known } \\
\text { enzymes and proteins. These enzymes catalyze the conversion of aldehydes and ketones to their } \\
\text { corresponding alcohols by utilizing NADH and/or NADPH as cofactors. }\end{array}$ \\
\hline CALML5 and CALML3 & Calcium-binding proteins (calmodulin family) \\
\hline UNC3 & Urocortin 3, endogenous ligand for corticotropin-releasing factor type 3 receptor \\
\hline$A S B 13$ & Ankyrin repeat and SOCS box containing 13 \\
\hline GDI2 & GDP dissociation inhibitor 2 \\
\hline FBXO18 & $\begin{array}{l}\text { F-box protein family. The F-box proteins constitute one of the } 4 \text { subunits of ubiquitin protein ligase } \\
\text { complex called SCFs which function in phosphorylation-dependent ubiquitination. }\end{array}$ \\
\hline IL15RA & $\begin{array}{l}\text { Interleukin } 15 \text { receptor alpha, cytokine receptor; enhances cell proliferation and expression of } \\
\text { apoptosis inhibitor BCL2L1/BCL2-XL }\end{array}$ \\
\hline$I L 2 R$ & $\begin{array}{l}\text { Interleukin receptor } 2 \text {, T cell growth factor receptor; confers lower immune responsiveness and } \\
\text { predisposes to type } 1 \text { diabetes }\end{array}$ \\
\hline$R B M 17$ & $\begin{array}{l}\text { RNA binding motif protein } 17 \text {. The encoded protein is part of the spliceosome complex and functions } \\
\text { in the second catalytic step of mRNA splicing. }\end{array}$ \\
\hline PFKFB3 & Synthesis and degradation of fructose 2,6-bisphosphate \\
\hline PRKCQ & $\begin{array}{l}\text { Protein kinase } \mathrm{C}(\mathrm{PKC}) \text { is a family of serine- and threonine-specific protein kinases. Each member of } \\
\text { the PKC family has a specific expression profile and is believed to play a distinct role. }\end{array}$ \\
\hline SFMBT2 & $\begin{array}{l}\text { Transcriptional repressor of HOXB13 gene. HOXB13 is a transcription factor that belongs to the } \\
\text { homeobox gene family. Genes of this family are highly conserved among vertebrates and essential for } \\
\text { vertebrate embryonic development. }\end{array}$ \\
\hline ITIH5, ITIH2 & $\begin{array}{l}\text { The inter-alpha-trypsin inhibitors (ITI) are a family of structurally related plasma serine protease } \\
\text { inhibitors involved in extracellular matrix stabilization and in prevention of tumor metastasis. }\end{array}$ \\
\hline ATP5C1 & Participates in the cellular response to DNA damage \\
\hline TAF3 & $\begin{array}{l}\text { TAFs contribute to promoter recognition and selectivity and act as antiapoptotic factors.TAF3 can } \\
\text { interact with several other transcription factors to control gene expression. }\end{array}$ \\
\hline GATA3 & $\begin{array}{l}\text { Encodes a protein which belongs to the GATA family of transcription factors, is an important } \\
\text { regulator of T cell development, and plays an important role in endothelial cell biology. Defects in this } \\
\text { gene are the cause of hypoparathyroidism with sensorineural deafness and renal dysplasia. }\end{array}$ \\
\hline
\end{tabular}

Genes in bold indicate possible contributors to the clinical phenotype.

10p15.3p14 Deletion in a Boy with Cleft Lip/Palate and Development Delay 


\section{Results and Discussion}

Conventional cytogenetic analysis revealed a normal 46 ,XY karyotype for both the patient and his father, and the mother had a normal 46,XX karyotype. Array-CGH results of the patient showed a 5.6-Mb interstitial deletion at $10 \mathrm{p} 15.3 \mathrm{p} 14$, spanning from position $2,834,518$ to $8,485,795$ bp (HG19) and encompassing several genes (fig. 2). Array-CGH of the parents was normal, indicating that it is a de novo deletion.

Chromosome 10p deletions have been described in approximately 60 patients with 2 main phenotypes: HDR and DGS2 syndromes [Lindstrand et al., 2010]. The first condition is associated with haploinsufficiency of the GATA3 gene [Van Esch et al., 2000] and the latter with partial monosomy 10p within the DGS2 region [Monaco et al., 1991; Melis et al., 2012]; however, phenotypic heterogeneity has also been noted in several instances [Tremblay et al., 2011; DeScipio et al., 2012].

In the present report, array-CGH analysis revealed a $5.6-\mathrm{Mb}$ deletion at $10 \mathrm{p} 15.3 \mathrm{p} 14$, encompassing several genes, including GATA3 (table 1). Patients with GATA3 haploinsufficiency usually present with hypoparathyroidism, heart defects, deafness, and renal malformations, while patients with partial monosomy 10p within the DGS2 region present with hypocalcemia, cardiovascular malformations, immunodeficiency, and facial dysmorphism, symptoms which are similar to those found in patients with 22q11.2 microdeletions. Our patient did not present with the usual findings of these conditions, although he did show growth retardation and developmental delay which have both been reported in patients with 10p15 deletions [Grunnarsson et al., 2009; Christopoulou et al., 2012].

Haploinsufficiency in 3 other genes (UNC3, IL15RA, $A K R 1 C 2)$ due to the deletion may contribute to these clinical manifestations. The UNC3 gene, the endogenous ligand for corticotropin-releasing factor type 3 receptor, is expressed in many tissues of the brain, including the hypothalamus, and is associated with mental retardation [Lindstrand et al., 2010]. The interleukin gene family (IL15RA) has neurological functions and is associated with synaptic transmission in the CNS, suggesting an involvement during embryogenesis [Kurowska et al., 2002]. The aldo-keto reductase family 1 , member $\mathrm{C} 2$ gene (AKR1C2) is related to 46,XY sex reversal and obesity, hyperphagia, and developmental delay; however, its effective function during development is poorly known.

Poor weight gain and feeding difficulties have been reported in patients with 10p deletions and, similarly to our patient, one patient showed no signs of hearing loss, renal dysplasia, or hypoparathyroidism [Lindstrand et al., 2010]. Cleft lip/palate was reported in 2 patients who had an involvement of chromosome 10p [Gottlieg et al., 1998; Lindstrand et al., 2010]. However, the phenotype observed in our patient is different from those previously reported in patients with $10 \mathrm{p}$ deletions.

Comparing the phenotype of our patient with the literature, he does not show any typical signs of the HDR and/or DGS2 syndromes, besides the developmental delay. The HDR syndrome is an autosomal dominant disorder, and all affected patients have hearing loss, while the other trait is more variable.

In summary, our patient presented with growth retardation, developmental delay, and cleft lip/palate which have been seldom reported in patients with 10p15 deletions. Despite this uncommon phenotype/genotype correlation, further investigations should be performed in order to clarify the role of the genes involved in relation to the phenotype presented by this patient.

\section{Acknowledgments}

We thank the patient and his parents for their collaboration. Genetics analysis was supported by grants from Fapesp (2010/18740-2 and 2011/07012-9).

References

Allemeersch J, Van Vooren S, Hannes F, De Moor B, Vermeesch JR, Moreau Y: An experimental loop design for the detection of constitutional chromosomal aberrations by array CGH. BMC Bioinformatics 10:380 (2009).

Christopoulou G, Tzetis M, Konstantinidou AE, Tsezou A, Kanavakis E, et al: Clinical and molecular description of a fetus in prenatal diagnosis with a rare de novo ring 10 and deletions of $12.59 \mathrm{Mb}$ in $10 \mathrm{p} 15.3 \mathrm{p} 14$ and 4.22 $\mathrm{Mb}$ in 10q26.3. Eur J Med Genet 55:75-79 (2012).

DeScipio C, Conlin L, Rosenfeld J, Tepperberg J, Pasion R, et al: Subtelomeric deletion of chromosome 10p15.3: clinical findings and molecular cytogenetic characterization. Am J Med Genet 158A:2152-2161 (2012).

Gottlieg S, Driscoll DA, Punnett HH, Sellinger B, Emanuel BS, Budarf ML: Characterization of $10 \mathrm{p}$ deletions suggests two nonoverlapping regions contribute to the DiGeorge syndrome phenotype. Am J Hum 62:495-498 (1998).

-Gunnarsson C, Graffmann B, Jonasson J: Chromosome $\mathrm{r}(10)(\mathrm{p} 15.3 \mathrm{q} 26.12)$ in a newborn child: case report. Mol Cytogenet 2:25 (2009).
Gamba/Rosenberg/Costa/Richieri-Costa/ Ribeiro-Bicudo 
Kurowska M, Rudnicka W, Maslinska D, Maśliński W: Expression of IL-15 and IL-15 receptor isoforms in select structures of human fetal brain. Ann N Y Acad Sci 966:441445 (2002).

Lichtner P, König R, Hasegawa T, Van Esch H, Meitinger T, et al: An HDR (hypoparathyroidism, deafness, renal dysplasia) syndrome locus maps distal to the DiGeorge syndrome region on 10p13/14. J Med Genet 37:33-37 (2000).
Lindstrand A, Malmgren H, Verri A, Benetti E, Eriksson M, et al: Molecular and clinical characterization of patients with overlapping $10 \mathrm{p}$ deletions. Am J Med Genet 152A:1233-1243 (2010).

Melis D, Genesio R, Boemio, Del Giudice E, Cappuccio $G$, et al: Clinical description of a patient carrying the smallest reported deletion involving 10p14 region. Am J Med Genet 158A:832-835 (2012).

Monaco G, Pignata C, Rossi E, Mascellaro O, Cocozza $\mathrm{S}$, et al: DiGeorge anomaly associated with 10p deletion. Am J Med Genet 39:215216 (1991).
Tremblay N, Yang SW, Hitz MP, Asselin G, Ginns $\mathrm{J}$, et al: Familial ventricular aneurysms and septal defects map to chromosome 10p15. Eur Heart J 32:568-573 (2011).

-Van Esch H, Groenen P, Nesbit MA, Schuffenhauer S, Lichtner P, et al: GATA3 haploinsufficiency causes human HDR syndrome. Nature 406:419-422 (2000).

Verri A, Maraschio P, Devriendt K, Uggetti C, Spadoni E, et al: Chromosome 10p deletion in a patient with hypoparathyroidism, severe mental retardation, autism and basal ganglia calcifications. Ann Genet 47:281287 (2004) 